\title{
Growth, Productivity and Water Use of Sunflower Crop Under Drip Irrigation System
}

\author{
${ }^{1}$ Saeed, A. A. Q., G. Abdel-Nasser ${ }^{2}$ and M. A. Gomaa ${ }^{3}$ \\ ${ }^{1}$ Ministry of Agriculture and Irrigation, Republic of Yemen \\ ${ }^{2}$ Soil and Agricultural Chemistry Dept. , ${ }^{3}$ Plant Production Dept. \\ Faculty of Agriculture (Saba Basha) - Alexandria University, Alexandria, EGYPT
}

\begin{abstract}
A field experiment of drip-irrigated Sunflower (Helianthus annuus) was conducted at the Experimental Farm, Faculty of Agriculture (Saba-Basha), Alexandria University, Egypt. The farm is located at Abees region $31^{\circ} 10.102^{\prime} \mathrm{N}$ and $29^{\circ} 58.085^{\prime} \mathrm{E}$ with altitude of $(-5 \mathrm{~m})$ under sea level, during 2013 growing season. The aim of the present study was initiated to assess the effect of irrigation regimes under drip irrigation method on sunflower growth, water consumptive use, water use efficiency and yield and yield components. The sunflower variety Sakha 53 was planted sowing date at $28^{\text {th }}$ April. Seeds were sown at 4-5 seeds in each hill with spacing of $0.3 \mathrm{~m}$ within each row and 0.6 spacing, then thinned to one plant after 2 weeks from sowing. After emergence, the plots were irrigated by the drip irrigation method. All field practices were done as usually recommended for sunflower cultivation. The present study consisted of 5 treatments. The irrigation treatments were based on replenishment of soil water depletion according to reference evapotranspiration $\left(\mathrm{ET}_{0}\right)$. The irrigation treatments were: Irrigation at $20,40,60,80$ and $100 \%$ of $\mathrm{ET}_{0}$. At harvest time (103 days after planting), some morphological characteristics of sunflower were determined such as: plant height $(\mathrm{cm})$, stem diameter $(\mathrm{cm})$, head diameter $(\mathrm{cm})$, leaves weight $(\mathrm{g})$, head weight $(\mathrm{g})$, seeds weight/ head $(\mathrm{g}), 100$ seeds weight and yield (ton ha ${ }^{-1}$ ), seed oil content $(\%)$ and oil yield $\left(\right.$ ton ha $\left.{ }^{-1}\right)$. Also, root weight $(\mathrm{g})$, length $(\mathrm{cm})$, width $(\mathrm{cm})$, chlorophyll content and some elemental contents. The results indicated that increasing the amount of irrigation water significantly increased plant height, stem diameter, head diameter, leaves weight/plant, head weight/plant, seeds weight/ head, 100 seeds weight, seed yield and oil yield. Also, root weight, length and width. The irrigation with 80 or $100 \%$ of $\mathrm{ET}_{0}$ has the same significant effect, thus the best irrigation is with $80 \%$ of $\mathrm{ET}_{0}$. Also, the value of water use efficiency of sunflower was decreased with increasing the amount of applied water. The increase in sunflower yield was due to both increase in yield content and oil yield in which sunflower yield was adversely affected by water deficit.
\end{abstract}

Keywords: sunflower, irrigation regime, water use efficiency, sunflower yield, root growth

\section{INTRODUCTION}

Sunflower (Helianthus annuus, L.) is one of the most important oil crops throughout most countries all over the world, and provides a major source of oil in human diet. However, it is considered as a relatively new crop in Egypt, in terms of production. Therefore, the response of sunflower crop to soil and water practices under Egyptian conditions must taken into account. A great emphasis should be given towards it for oil production due to the crop advantages and adaptability to various environmental conditions (Berglund, 2003).

Sunflower (Helianthus annus, L.) is one of the most widely cultivated oil crop in the world. Because of moderate cultivation requirements and high oil yield, planted area has increased in recent years (Shehata and Elkhawas, 2003). 
Sunflower seeds contain high amount of oil (40 to $50 \%$ ), which is an important source of polyunsaturated fatty acid (Linoleic acid) of potential health benefits.

In dry land cropping systems, water is the most important limiting factor for crop production (Ashrafi and Razmjoo, 2009).On one hand, the most important factors that decrease crop growth and also affect on 40 to 60 percent of agricultural lands is drought stress (Reddy et al., 2004). This problem is very important in Iran that located in arid and semiarid regions and also water requirements of crops due to lack of precipitation mainly provided by irrigation (Sepaskhah and Khajehabdollahi, 2005). as well as, It is well known that adequate water supply is considered as a very important factor that affect the accumulation of dry matter in the plant, as well as, vegetative growth of most crops (Aminifar et al., 2012). Water deficit, extreme temperatures and low atmospheric humidity all contribute to drought, which is one of the most detrimental factors affecting crop yield (Szilgyi 2003).

It has been shown that, sometimes, periods of reduced growth may trigger physiological processes that actually increase yield (Smith et al., 2002). Severe water deficits during the early vegetative growth result in reduced plant height but may increase root depth. Adequate water during the late vegetative period is required for proper bud development. The flowering period is the most sensitive to water deficits which cause considerable yield decrease since fewer flower come to full development (Beyazgul et al., 2000; Ali and Shui, 2009). Seed formation is the next most sensitive period to water deficit, causing severe reduction in both yield and oil content (Doorenbos and Kassam, 1979). According to Casadebaig et al., (2008), minimization of water loss in response to water deficit is a major aspect of drought tolerance and can be achieved through the lowering of either leaf area expansion rate or transpiration per unit leaf area (stomata conductance). Although sunflower is known to be a drought tolerant crop or grown under dry land conditions, substantial yield increases can be achieved by supplementary irrigation, which is one of the most effective strategies to mitigate the effects of dry spells in crop production (Fox and Rockstrom, 2000; Xiao et al., 2007).

When water supply does not meet crop water requirements, actual evapotranspiration $\left(E T_{a}\right)$ will fall below maximum evapotranspiration $\left(E T_{m}\right)$. Under this condition, water stress will develop in the plant, which adversely affects crop growth and ultimately crop yield. The effect of water stress on growth and yield depends on the crop species, variety, magnitude and time of occurrence of water deficit. The effect of the timing of water deficit on crop growth and yield is of major importance in scheduling available but limited water supply over growing periods of the crops and in determining the priority of water supply amongst crop during the growing season (Doorenbos and Kassam, 1979).

The present study was initiated to assess the effect of irrigation regimes under drip irrigation method on sunflower growth, water consumptive use, water use efficiency and yield and yield components. 


\section{MATERIALS AND METHODS}

\section{Experimental site and conditions}

This study was conducted during the 2013 summer season at the Experimental Farm, Faculty of Agriculture (Saba-Basha), Alexandria University, Egypt. The farm is located at Abees region located at $31^{\circ} 10.102^{\prime} \mathrm{N}$ and $29^{\circ}$ $58.085^{\prime} \mathrm{E}$ with altitude of $(-5 \mathrm{~m})$ under sea level. The site was planted with corn crop in previous season. This area is characterized by a semi-arid climate, the weather is hot and dry from May to August where temperatures varies from 25-30 ${ }^{\circ} \mathrm{C}$. On the other hand, the rainfall occures in winter with an average of $186.2 \mathrm{~mm}$ per year. Wind speed average $13.5 \mathrm{~km} /$ day and relative humidity averages about $69.5 \%$. Some climatological data on the experimental site were taken from Nouzha Weather Station are given in Table (1).

\section{Soil of the experimental site}

Soil samples were collected from the experimental soil for both surface (0$10 \mathrm{~cm}),(10-20 \mathrm{~cm})$ and subsurface $(20-40 \mathrm{~cm})$. Some physical and chemical properties of the experimental field soil are presented in Table (2). The soil properties were performed according to the methods outlined in Carter and Gregorich (2008). The soil of the experimental site is clayey texture with water table level of $1 \mathrm{~m}$ down the soil surface, the groundwater is moderately saline (2.5 $\mathrm{dS} / \mathrm{m})$. The contribution of water table to plant water requirements is low in the site of experiment. Table (3) shows the chemical analysis of irrigation water.

\section{Sunflower cultivation}

Sunflower (Helianthus annuus, L.) variety Sakha 53, early variety (100 days crop age) was selected for the study at 2013 summer season. Plant sowing date was at 28 April, 2013. Seeds were sown at 4-5 seeds in each hill with spacing of $0.3 \mathrm{~m}$ within each row. Thinning to one plant per hill was carried out after 15 days from sowing, to obtain a final plant population of 55500 plants/ha. After emergence, the plots were irrigated by the drip irrigation method. Irrigation was terminated at 5 August, complete canopy and initial blooming date was at 13 June, and harvesting data was at 9 August. All field practices were done as usually recommended for sunflower cultivation. Phosphorus fertilizer as calcium superphosphate (15.5\% $\mathrm{P}_{2} \mathrm{O}_{5}$ ) was fully added to the soil during seed preparation at $336 \mathrm{~kg} \mathrm{P}_{2} \mathrm{O}_{5} \mathrm{ha}^{-1}$. Ammonium Nitrate $(33.5 \% \mathrm{~N})$ at the rate of $168 \mathrm{~kg} \mathrm{ha}^{-1}$ were applied at two equal doses, one after sowing and the second after one month later. Potassium Sulfate $\left(48 \% \mathrm{~K}_{2} \mathrm{O}\right)$ at the rate of $67 \mathrm{~kg} \mathrm{ha}^{-1}$ were added at two equal doses, one after sowing and the second after one month later. 
Table (1). Daily maximum, minimum and average temperature, wind speed, solar radiation for the experimental site during the experimental period

\begin{tabular}{ccccccccc}
\hline $\begin{array}{c}\text { Growing } \\
\text { Months }\end{array}$ & $\begin{array}{c}\text { Average } \\
\text { minimum } \\
\text { daily } \\
\text { temperature } \\
\mathbf{T}_{\min }\left({ }^{\circ} \mathbf{C}\right)\end{array}$ & $\begin{array}{c}\text { Average } \\
\text { maximum } \\
\text { daily } \\
\text { temperature } \\
\mathbf{T}_{\max }\left({ }^{\circ} \mathbf{C}\right)\end{array}$ & $\begin{array}{c}\text { Average } \\
\text { daily } \\
\text { temperature } \\
\mathbf{T}_{\mathbf{m}}\left({ }^{\circ} \mathbf{C}\right)\end{array}$ & $\begin{array}{c}\text { Average } \\
\text { daily } \\
\text { wind } \\
\mathbf{s p e e d} \\
\mathbf{U}_{\mathbf{2}}(\mathbf{m} / \mathbf{s})\end{array}$ & $\begin{array}{c}\text { Average } \\
\text { relative } \\
\text { humidity } \\
\%\end{array}$ & $\begin{array}{c}\text { Average } \\
\text { atmospheric } \\
\text { pressure } \\
\mathbf{m b}\end{array}$ & $\begin{array}{c}\text { Average } \\
\text { precipitation } \\
\mathbf{m m} / \mathbf{m o n t h}\end{array}$ & $\begin{array}{c}\text { Average } \\
\text { daily solar } \\
\text { radiation } \\
\left(\mathbf{M J} / \mathbf{m}^{2} / \mathbf{d a y}\right)\end{array}$ \\
\hline April & 14.8 & 24.6 & 19.4 & 11.18 & 62.9 & 1014.8 & 0.0 & 34.12 \\
May & 18.8 & 28.7 & 23.5 & 9.79 & 68.0 & 1012.4 & 3.1 & 35.90 \\
June & 21.7 & 30.3 & 25.6 & 10.83 & 68.4 & 1011.1 & 0.0 & 37.41 \\
July & 23.4 & 30.2 & 26.6 & 11.66 & 71.4 & 1008.1 & 0.0 & 36.64 \\
August & 23.9 & 31.7 & 27.8 & 9.58 & 72.1 & 1008.9 & 0.0 & 34.99 \\
\hline
\end{tabular}


J. Adv. Agric. Res. (Fac. Agric. Saba Basha)

Table (2). Some soil physical and chemical properties of experimental site used in the present study.

\begin{tabular}{|c|c|c|c|c|}
\hline Soil parameters & $\begin{array}{c}0-10 \mathrm{~cm} \\
\text { depth }\end{array}$ & $\begin{array}{c}10-20 \mathrm{~cm} \\
\text { depth }\end{array}$ & $\begin{array}{l}20-40 \mathrm{~cm} \\
\text { depth }\end{array}$ & Unit \\
\hline \multicolumn{5}{|l|}{ Particle size distribution } \\
\hline Sand & 29.7 & 29.7 & 32.2 & $\%$ \\
\hline Silt & 15.0 & 17.5 & 15.0 & $\%$ \\
\hline Clay & 55.3 & 52.8 & 52.8 & $\%$ \\
\hline Textural class & Clay & Clay & Clay & - \\
\hline Soil bulk density & 1.24 & 1.25 & 1.25 & $\mathrm{Mg}$ \\
\hline Soil moisture content at field capacity $\left(\theta_{\mathrm{fc}}\right)$ & 0.351 & 0.361 & 0.369 & $\mathrm{~m}^{3} \mathrm{~m}$ \\
\hline Soil moisture content at permanent wilting point $\left(\theta_{\mathrm{wp}}\right)$ & 0.122 & 0.128 & 0.129 & $\mathrm{~m}^{3} \mathrm{~m}$ \\
\hline Plant available water content (PAW) & 0.229 & 0.233 & 0.239 & $\mathrm{~m}^{3} \mathrm{~m}$ \\
\hline Organic matter content & 2.87 & 2.87 & 2.15 & $\%$ \\
\hline Total calcium carbonate & 18.12 & 18.12 & 15.78 & $\%$ \\
\hline Electrical Conductivity $\left(\mathrm{EC}_{\mathrm{w}}\right),(1: 1$, soil: water extract $)$ & 6.98 & 6.29 & 5.94 & dS \\
\hline $\mathrm{pH}(1: 1$, soil : water suspension) & 8.05 & 8.15 & 8.25 & - \\
\hline \multicolumn{5}{|l|}{ Soluble Cations } \\
\hline $\mathrm{Ca}^{2+}$ & 2.38 & 1.69 & 1.42 & meq \\
\hline $\mathrm{Mg}^{2+}$ & 7.85 & 6.05 & 4.50 & meq \\
\hline $\mathrm{Na}^{+}$ & 58.15 & 54.13 & 52.13 & meq \\
\hline $\mathrm{K}^{+}$ & 1.35 & 1.12 & 1.12 & meq \\
\hline \multicolumn{5}{|l|}{ Soluble Anions } \\
\hline $\mathrm{CO}^{=}{ }_{3+} \mathrm{HCO}^{-3}$ & 10.20 & 9.92 & 2.12 & meq \\
\hline $\mathrm{Cl}^{-}$ & 44.00 & 44.39 & 41.00 & meq \\
\hline $\mathrm{SO}_{4}$ & 14.03 & 7.70 & 12.54 & meq \\
\hline
\end{tabular}

Table (3). Chemical analysis of irrigation water used in the field experiment.

\begin{tabular}{ccc}
\hline Parameters & Value & unit \\
\hline $\mathrm{pH}$ & 7.35 & - \\
$\mathrm{EC}_{\text {iw }}$ & 0.60 & $\mathrm{dS} \mathrm{m}{ }^{-1}$ \\
\hline Soluble Cations & & \\
\hline $\mathrm{Ca}^{+2}$ & 1.89 & $\mathrm{meql}^{-1}$ \\
$\mathrm{Mg}^{+2}$ & 0.81 & meql $^{-1}$ \\
$\mathrm{~K}^{+}$ & 2.74 & meql $^{-1}$ \\
$\mathrm{Na}^{+}$ & 0.46 & meql $^{-1}$ \\
\hline Soluble Anions $_{\mathrm{CO}^{-}}{ }_{3}+\mathrm{HCO}^{-}$ & & \\
$\mathrm{Cl}^{-}$ & 1.98 & meql $^{-1}$ \\
$\mathrm{SO}_{4}^{-2}$ & 0.81 & meql $^{-1}$ \\
\end{tabular}


Harvesting was done after 103 days from planting (9 August, 2013). Plant samples were taken from each plot (replicate) on the basis of one longitudinal meter of each line, to determine some morphological characteristics such as: plant height $(\mathrm{cm})$, stem diameter $(\mathrm{cm})$, head diameter $(\mathrm{cm})$, leaves weight $(\mathrm{g})$, head weight $(\mathrm{g})$, seeds weight/ head $(\mathrm{g}), 100$ seeds weight and yield (ton ha ${ }^{-1}$ ) and oil yield(ton ha-1). Also, root weight $(\mathrm{g})$, length $(\mathrm{cm})$ and width $(\mathrm{cm})$. Roots were washed with distilled water and let to dry then roots were imaging with digital camera. At harvest, the sample of plants $(1 \mathrm{~m}$ of the row $\times 0.60 \mathrm{~m}$ width of the row $=0.60 \mathrm{~m}^{2}$ ) of the two central ridge were chosen to determine the sunflower yield. The total yield per ha ${ }^{-1}$ was calculated.

\section{Irrigation regime}

The present study consisted of 5 treatments. The irrigation treatments were based on replenishment of soil water depletion according to the reference evapotranspiration $\left(\mathrm{ET}_{0}\right)$. The irrigation treatments were:

11 irrigation at $20 \%$ of $\mathrm{ET}_{0}$,

12 irrigation at $40 \%$ of $\mathrm{ET}_{0}$,

13 irrigation at $60 \%$ of $\mathrm{ET}_{0}$,

14 irrigation at $80 \%$ of $\mathrm{ET}_{0}$, and

I5 irrigation at $100 \%$ of $\mathrm{ET}_{0}$

A drip irrigation system (Fig. 1) was designed for the experiment. Irrigation water was taken by a water pump. Distribution lines consisted of PVC pipe manifolds for each plot. The diameter of the polyethylene laterals were $16 \mathrm{~mm}$ and each lateral irrigated one plant row. The inline emitter discharge rate was $4 \mathrm{I}$ $\mathrm{h}^{-1}$ at $100 \mathrm{kPa}$ operating pressure. The actual emitter discharge rate was calibrated before starting the experiment. The drip network calibration was performed and the actual rate of emitter was $3.43 \mathrm{I} \mathrm{h}^{-1}$.

Soil water content was measured by sampling a soil from each row with soil tube $0.025 \mathrm{~m}$ diameter at three depths i.e. 0-10, 10-20 and 20-40 cm below soil surface then determined by gravimetric method. Soil water contents were monitored prior each irrigation and after irrigation at surface and subsurface depths through electronic pressure transducer (electronic tensimeter).

\section{Crop Evapotranspiration}

The irrigation requirements were calculated according to the PenmanMonteith equation (Allen et al., 1998) according the following equation:

$$
\mathrm{ET}_{\text {crop }}=\frac{\mathrm{ET}_{\text {drip }}}{\mathrm{E}_{\mathrm{a}}(1-\mathrm{LR})}
$$

Where:

$\mathrm{ET}_{\text {crop }}$ is the crop evapotranspiration, $\mathrm{mm} /$ day

$\mathrm{ET}_{\text {drip }}$ is the crop evapotranspiration under drip irrigation system, $\mathrm{mm} /$ day

$E_{a}$ is the efficiency of irrigation system (assumed as $90 \%$ for drip irrigation system under the present conditions).

$\mathrm{LR}$ is the Leaching Requirements required for salt leaching in the root zone depth (assumed as $15 \%$ ). and 
$\mathrm{ET}_{\text {drip }}=\mathrm{K}_{\mathrm{r}} \times \mathrm{K}_{\mathrm{c}} \times \mathrm{ET}_{0}$

$\mathrm{K}_{\mathrm{r}}$ is the reduction factor that reflects the percent of soil covering by crop canopy.

$\mathrm{K}_{\mathrm{r}}$ can be calculated by the equation described in Karmeli and Keller (1975):

$\mathrm{K}_{\mathrm{r}}=\frac{\mathrm{GC}}{0.85}$

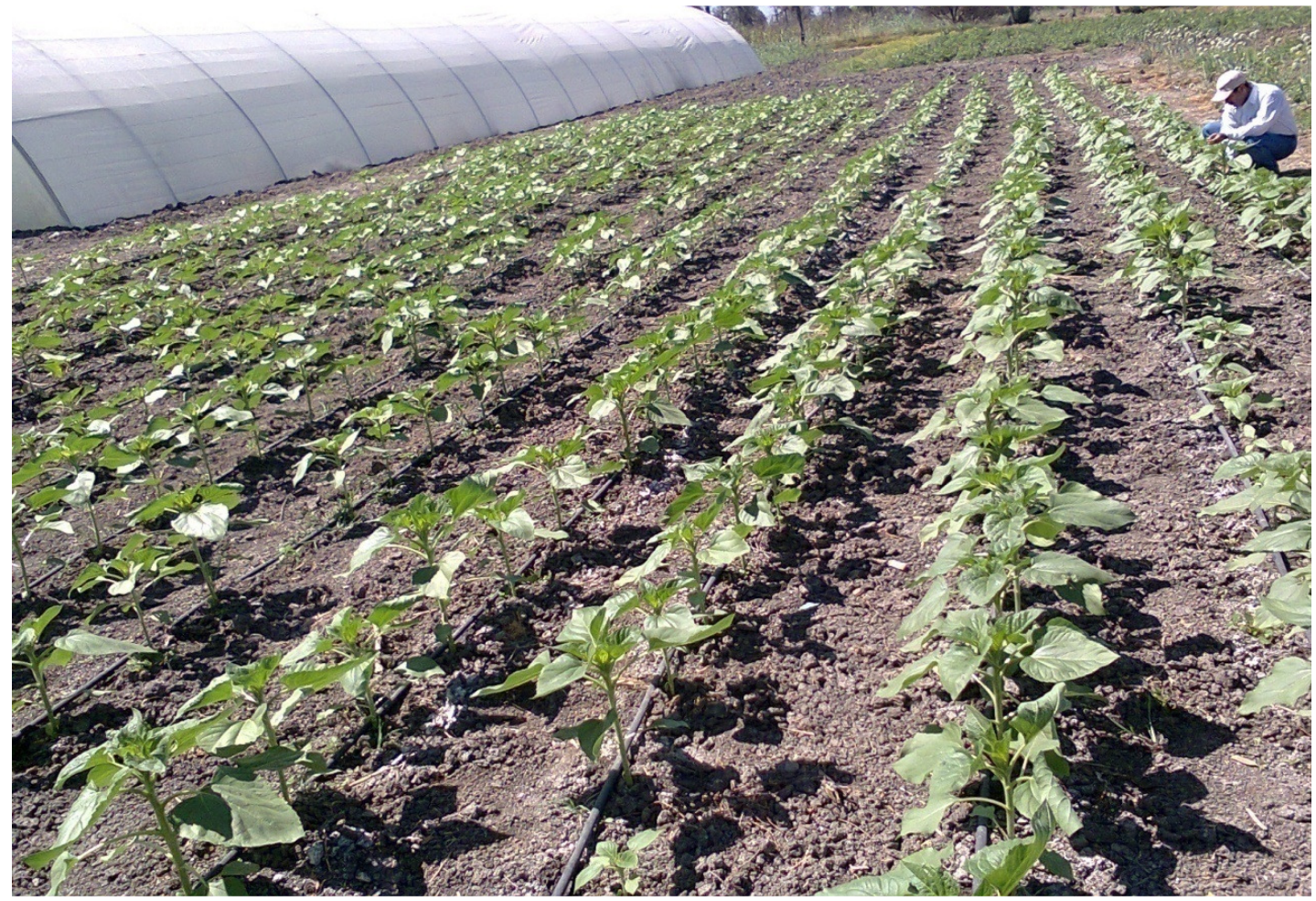

Fig. (1). General picture of the sunflower field experiment one month after cultivation

Where, GC is the ground cover fraction (plant canopy area divided by soil area occupied by one plant, assumed as 0.6 ).

$\mathrm{K}_{\mathrm{c}}$ is the crop coefficient ranging from 0.35 (for initial stage) to 1.15 (for development stage) for sunflower crop (Allen et al., 1998).

The length and crop coefficient $\left(\mathrm{K}_{\mathrm{c}}\right)$ were needed for each the 4 growth stages: initial, crop development, mid-season and late season stages. The crop coefficients $\left(\mathrm{K}_{\mathrm{c}}\right)$ were collected from FAO (Allen et al., 1998) and are presented in Table (4). 
J. Adv. Agric. Res. (Fac. Agric. Saba Basha)

Table (4).Crop coefficient $\left(K_{c}\right)$ and development stages period for sunflower

\begin{tabular}{lcc}
\hline \multicolumn{1}{c}{ Growth stage } & $\mathbf{K}_{\mathbf{c}}$ & Stage period, days \\
\hline Initial & 0.35 & 20 \\
Crop development & $0.35-1.15$ & 25 \\
Mid-season & 1.15 & 38 \\
Late-season & $1.15-0.35$ & 20
\end{tabular}

$\mathrm{ET}_{0}$ is the reference evapotranspiration calculated with FAO PenmanMonteith equation (Allen et al., 1998) according the climatic data collected from the Nouzha Weather Station. The equation is expressed as:

$$
E T_{0}=\frac{0.408 \Delta\left(R_{n}-G\right)+\gamma \frac{900}{T+273} U_{2}\left(e_{s}-e_{a}\right)}{\Delta+\gamma\left(1+0.34 U_{2}\right)}
$$

\section{Where:}

$\mathbf{E T}_{0} \quad$ Reference evapotranspiration, $\mathrm{mm}_{\text {day }}{ }^{-1}$

$\mathbf{R}_{\mathbf{n}} \quad$ Net radiation at the crop surface, $\mathrm{MJ} \mathrm{m}^{-2}$ day $^{-1}$,

G Soil heat flux density, $\mathrm{MJ} \mathrm{m}^{-2}$ day $^{-1}$, Generally very small and assumed to be zero).

T Mean daily air temperature at $2.0 \mathrm{~m}$ height, ${ }^{\circ} \mathrm{C}$,

$\mathbf{U}_{2} \quad$ Wind speed at $2 \mathrm{~m}$ height, $\mathrm{m} \mathrm{s}^{-1}$,

$\mathbf{e}_{\mathbf{s}} \quad$ Saturation vapor pressure at 1.5 to $2.5-\mathrm{m}$ height, $\mathrm{kPa}$,

$\mathrm{e}_{\mathrm{a}} \quad$ Actual vapor pressure at 1.5 to $2.5-\mathrm{m}$ height, $\mathrm{kPa}$,

$\mathbf{e}_{\mathbf{s}}-\mathbf{e}_{\mathbf{a}} \quad$ Saturation vapor pressure deficit, $\mathrm{KPa}$,

$\Delta \quad$ Slope vapor pressure curve, $\mathrm{kPa}^{\circ} \mathrm{C}^{-1}$,

$\gamma \quad$ Psychrometric constant, $\mathrm{kPa}^{\circ} \mathrm{C}^{-1}$.

\section{Seed oil content}

The oil percentage of seeds was estimated using Soxhelt apparatus and petroleum ether as a solvent according to the method outlined in AOAC (1995). Oil yield (ton ha ${ }^{-1}$ ) was calculated by multiplying seed oil percentage by seed yield per ha ${ }^{-1}$.

\section{Soil analysis}

\section{Soil physical analysis}

Particle size distribution: Soil mechanical analysis was carried out using hydrometer method according to (Klute, 1986), using sodium hexametaphosphate $\left(\left(\mathrm{NaPO}_{3}\right)_{13}\right)$ as dispersing agent.

Soil moisture content: Soil moisture is routinely measured in most field trials. The gravimetric approach is more flexible, as samples can be readily taken from any soil situation. All analyses in the laboratory are related to oven-dry basis. The 
soil sample was dried in an oven at $105^{\circ} \mathrm{C}$ for $24 \mathrm{~h}$, next day remove from oven; fit the lid cool for at least 30 minutes and re-weight (Hesse, 1971).

Soil chemical analysis:

The soil samples were air dried, passed through a $2 \mathrm{~mm}$ sieve and analyzed according to the following procedures (Page, 1982):

Total carbonates content

Was estimated volumetrically using calcimeter and calculated as calcium carbonate percentage according to Richards (1972).

\section{Organic matter content}

Organic carbon (OC) was determined using modified Walkley-Blacks titration method (Carter and Gregorich, 2008). The organic matter content (OM) was calculated using the suitable constant $(O M=1.724 \times O C)$.

\section{Total soluble salts}

Electrical conductivity (EC) of soil: water extract, 1:2 (w/v) was measured using conductivity meter according to Jackson (1973).

\section{Soluble Calcium and Magnesium}

Soluble calcium and magnesium in soil: water extract were determined volumetrically by the versenate method (EDTA) using ammonium purpurate as an indicator for calcium and Erichrome black $\mathrm{T}$ for calcium plus magnesium (Jackson, 1973).

\section{Soluble Sodium and Potassium}

Soluble sodium and potassium was determined photometrically using flame photometer according to Jackson (1973).

\section{Soluble Carbonates and Bicarbonates}

Soluble carbonates and bicarbonates were determined volumetrically by titration against $0.1 \mathrm{~N}$ hydraulic acid using phenolphthalein and methyl orange as indicators (Jackson, 1973).

\section{Soluble Chlorides}

Soluble chlorides were determined by titration against $0.05 \mathrm{~N}$ Silver nitrate solution and potassium chromate as an indicator (Jackson, 1973).

\section{Soluble sulfates}

Soluble sulfates were determined by turbidity method as indicated in (Jackson, 1973).

\section{Chemical analysis of irrigation water}

Chemical analysis of irrigation water including water reaction $(\mathrm{pH})$, electric conductivity $(E C)$, and soluble cations and anions were done according to page (1982).

\section{Statistical analysis}

All collected data for Sunflower growth, yield and yield components were subjected to analysis of variance (ANOVA) according to Snedecor and Cochran (1991). The mean values were compared according to least significant difference Test (LSD test), Williams and Abdi (2010). All statistical analyses were performed using analysis of variance technique of "Statistix 8" computer software package (Statistix, 2003). 


\section{RESULTS AND DISCUSSION}

\section{Sunflower growth characters}

The results presented in Table (5) show the response of sunflower growth characters as affected by different irrigation regimes. The results indicated a significant effect of different irrigation regimes in all sunflower growth characters as compared with control $\left(100 \%\right.$ of $\left.\mathrm{ET}_{0}\right)$. Irrigation at $80 \%$ of $\mathrm{ET}_{\circ}$ gave a highest value of plant height $(169.77 \mathrm{~cm})$ and head diameter $(23.77 \mathrm{~cm})$, steam diameter $(2.33 \mathrm{~cm})$, leaf weight/plant $(320.67 \mathrm{~g})$, stem weight/plant $(494.0 \mathrm{~g})$, head weight/plant $(506.87 \mathrm{~g})$ and Irrigation at $100 \%$ of $\mathrm{ET}_{0}$ gave a highest values for all parameters. Also the results presented in Table (5) show significant effect of different irrigation regimes on number of green leaves/plant (29.0) at $100 \%$ of $\mathrm{ETT}_{0}$, and chlorophyll b content $\left(0.160 \mathrm{mg} / 100 \mathrm{~g}\right.$ leaf fresh weight) at $20 \%$ of $\mathrm{ET}_{0}$. Total chlorophyll and chlorophyll a content have not significant effect at different irrigation regimes.

The reduction of vegetative growth as a result of decreasing amount of irrigation $\left(60 \%\right.$ of $\left.\mathrm{ET}_{0}\right)$ may be due to the major effect of water stress in decreasing the water uptake by root system as a result of decreasing root function (Rowe and Bearsell, 1973). The present results are in accordance of the previous results of Abdel-Nasser (1991) and Abdel-Nasser and EL-Shazly (2000).

Table (5). Growth characters of sunflower as affected by irrigation regimes

\begin{tabular}{ccccccc}
\hline $\begin{array}{c}\text { Irrigation } \\
\text { Treatment } \\
\left(\% \text { of } \mathrm{ET}_{\mathbf{0}}\right)\end{array}$ & $\begin{array}{c}\text { Plant } \\
\text { height } \\
(\mathbf{c m})\end{array}$ & $\begin{array}{c}\text { Head } \\
\text { diameter } \\
(\mathbf{c m})\end{array}$ & $\begin{array}{c}\text { Stem } \\
\text { diameter } \\
(\mathbf{c m})\end{array}$ & $\begin{array}{c}\text { Stem } \\
\text { weight } / \\
\text { plant }(\mathbf{g})\end{array}$ & $\begin{array}{c}\text { Head } \\
\text { weight } / \\
\text { plant }(\mathbf{g})\end{array}$ & $\begin{array}{c}\text { Leaves } \\
\text { weight } / \\
\text { plant }(\mathbf{g})\end{array}$ \\
\hline 20 & 161.67 & $19.37 \mathrm{c}$ & $1.62 \mathrm{~b}$ & 304.67 & 377.27 & $131.00 \mathrm{C}$ \\
40 & 164.00 & $19.80 \mathrm{C}$ & $1.64 \mathrm{~b}$ & 344.90 & 393.37 & $231.67 \mathrm{~b}$ \\
60 & 168.77 & $21.39 \mathrm{~b}$ & $1.76 \mathrm{~b}$ & $451.83 \mathrm{c}$ & 394.17 & $250.67 \mathrm{~b}$ \\
80 & 169.77 & $23.77 \mathrm{a}$ & $2.33 \mathrm{a}$ & 494.00 & 506.87 & $320.67 \mathrm{a}$ \\
100 & 169.83 & $22.87 \mathrm{a}$ & $2.35 \mathrm{a}$ & 592.00 & 535.00 & $318.00 \mathrm{a}$ \\
LSD & $3.07^{*}$ & $1.28^{*}$ & $0.27^{*}$ & $40.65^{*}$ & $76.607^{*}$ & $31.226^{*}$ \\
\hline
\end{tabular}

Table (5). Cont....

\begin{tabular}{ccccc}
\hline $\begin{array}{c}\text { Irrigation } \\
\text { Treatment } \\
\left(\% \text { of } \mathrm{ET}_{\mathbf{0}}\right)\end{array}$ & $\begin{array}{c}\text { Number of } \\
\text { green leaves / } \\
\text { plant }\end{array}$ & $\begin{array}{c}\text { Chlorophyll a } \\
(\mathbf{m g} / \mathbf{g})\end{array}$ & $\begin{array}{c}\text { Chlorophyll b } \\
(\mathbf{m g} / \mathbf{g})\end{array}$ & $\begin{array}{c}\text { Total chlorophyll } \\
(\mathbf{m g} / \mathbf{g})\end{array}$ \\
\hline 20 & $25.3 \mathrm{~b}$ & 0.163 & $0.160 \mathrm{a}$ & 0.323 \\
40 & $26.7 \mathrm{ab}$ & 0.150 & $0.100 \mathrm{~b}$ & 0.250 \\
60 & $28.7 \mathrm{ab}$ & 0.180 & $0.117 \mathrm{ab}$ & 0.297 \\
80 & $28.3 \mathrm{ab}$ & 0.170 & $0.083 \mathrm{~b}$ & 0.253 \\
100 & $29.0 \mathrm{a}$ & 0.157 & $0.080 \mathrm{~b}$ & 0.237 \\
LSD $(0.05)$ & $3.4^{*}$ & $0.128 \mathrm{NS}$ & $0.058^{*}$ & $0.167 \mathrm{NS}$ \\
\hline
\end{tabular}


Root growth The root growth was expressed as the root length and root lateral extension of sunflower. The data are illustrated in Table (6). The data showed that root length increased with increasing irrigation water. The highest value was attained with irrigation at $100 \%$ of $\mathrm{ET}_{0}$. The irrigation with 80 or $100 \%$ of $\mathrm{ET}_{0}$ has the same significant effect, thus the best irrigation is with $80 \%$ of $\mathrm{ET}_{0}$. The same trend was noticed with root lateral extension (width) in which irrigation with $60 \%$ of $\mathrm{ET}_{0}$ is the best water regime to obtain the significant extension of sunflower root.

Table (6). Root length and width at harvest of sunflower as affected by irrigation regime.

\begin{tabular}{|c|c|c|c|}
\hline $\begin{array}{c}\text { Irrigation Treatment } \\
\left(\% \text { of } E T_{0}\right)\end{array}$ & $\begin{array}{c}\text { Root weight/plant } \\
\text { (g) }\end{array}$ & $\begin{array}{l}\text { Root length } \\
\text { (cm) }\end{array}$ & $\begin{array}{l}\text { Root width } \\
\text { (cm) }\end{array}$ \\
\hline 20 & $124.83 \mathrm{c}$ & $11.8 \mathrm{e}$ & $27.5 \mathrm{c}$ \\
\hline 40 & $125.50 \mathrm{c}$ & $13.2 \mathrm{~d}$ & $28.7 \mathrm{~b}$ \\
\hline 60 & $187.93 \mathrm{bc}$ & $14.7 \mathrm{c}$ & $29.7 \mathrm{a}$ \\
\hline 80 & $194.67 \mathrm{~b}$ & $15.0 \mathrm{a}$ & $29.9 \mathrm{a}$ \\
\hline 100 & $263.93 \mathrm{a}$ & $15.4 \mathrm{a}$ & $30.1 \mathrm{a}$ \\
\hline LSD (0.05) & $66.345^{*}$ & $2.8569^{*}$ & $9.1566^{*}$ \\
\hline
\end{tabular}

Yield and yield components

Data presented in Table (7) show the effect of water irrigation regimes treatments on seed and oil yields. The result clearly indicated significant effect of different irrigation regimes on sunflower yield and yield characters, seed yield/plant (g), 100-seed weight $(\mathrm{g})$, gross seed yield (ton ha ${ }^{-1}$ ), seed oil content (\%) and seed oil yield (ton ha ${ }^{-1}$ ). Irrigation at $80 \%$ of $\mathrm{ET}_{\text {o gave highest significant }}$ value of seed yield/plant $(105.00 \mathrm{gm}), 100$-seed weight $(8.87 \mathrm{~g})$, gross seed yield $\left(5.83\right.$ ton ha $\left.{ }^{-1}\right)$ and seed oil content $(45.67 \%)$. The highest value of seed oil yield (2.759 ton ha ${ }^{-1}$ ) was attained at irrigation with $100 \% \mathrm{ET}_{0}$. The results are in parallel with those obtained by Kssab et al. (2012) and Abdel-Mawgoud et al. (2009).

Table (7). Seed yield and yield components as affected by irrigation regimes.

\begin{tabular}{|c|c|c|c|c|c|}
\hline $\begin{array}{l}\text { Irrigation } \\
\text { Treatment } \\
\left.\text { (\% of } \mathrm{ET}_{0}\right)\end{array}$ & $\begin{array}{c}\text { Seed } \\
\text { yield/plant } \\
\text { (g/plant) }\end{array}$ & $\begin{array}{c}\text { 100-seed } \\
\text { weight } \\
\text { (g) }\end{array}$ & $\begin{array}{c}\text { Gross seed } \\
\text { yield } \\
{\text { (ton } \mathrm{ha}^{-1} \text { ) }}^{\text {Gel }}\end{array}$ & $\begin{array}{c}\text { Seed oil } \\
\text { Content } \\
(\%)\end{array}$ & $\begin{array}{l}\text { Oil yield } \\
\left(\text { ton } \mathrm{ha}^{-1}\right)\end{array}$ \\
\hline 20 & $84.67 \mathrm{~b}$ & $7.37 \mathrm{~b}$ & $4.704 \mathrm{~b}$ & $40.00 \mathrm{~b}$ & $1.883 \mathrm{C}$ \\
\hline 40 & $89.17 \mathrm{ab}$ & $8.30 \mathrm{a}$ & $4.954 a b$ & $44.00 \mathrm{a}$ & $2.184 \mathrm{bc}$ \\
\hline 60 & $91.53 \mathrm{ab}$ & $8.47 \mathrm{a}$ & $5.085 \mathrm{ab}$ & $45.33 \mathrm{a}$ & $2.302 \mathrm{abc}$ \\
\hline 80 & $105.00 \mathrm{a}$ & $8.67 \mathrm{a}$ & $5.833 \mathrm{a}$ & $45.67 \mathrm{a}$ & $2.669 a b$ \\
\hline 100 & $106.17 \mathrm{a}$ & $8.87 \mathrm{a}$ & $5.898 \mathrm{a}$ & $46.67 \mathrm{a}$ & $2.759 \mathrm{a}$ \\
\hline LSD 0.05 & $18.497^{*}$ & $0.77^{*}$ & $1.028^{*}$ & $2.30^{*}$ & $0.555^{\star}$ \\
\hline
\end{tabular}




\section{Leaf elemental content}

The results presented in Table (8) show the response of sunflower growth characters to different irrigation regimes. The results indicated a significant effect of different irrigation regimes in all some elemental contents of sunflower leave as affected by irrigation regime. Irrigation at $60 \%$ of $\mathrm{ET}_{0}$ gave highest values of nitrogen $(1.74 \%)$ and potassium $(3.35 \%)$ and $(3.40 \%)$ at $100 \% \mathrm{ET}_{0}$. The highest value of Phosphorus (0.37\%) was attained at irrigation with $100 \%$ and $80 \% \mathrm{ET}_{0}$.

This result is true because of by increasing water stress, the plant has less ability to absorb water. Thus, the nutrients uptake decreased. Also, such reduction in chlorophyll content may be attributed to the role of water as a substrate for all vital processes in plant tissue especially in chlorophyll formation (Abdel-Nasser and El-Shazly, 2000 and Abdel-Nasser and Hussein, 2001). Such a reduction may be explained on the basis that under water stress, the soil moisture became unavailable to root uptake, thereby, decreased nutrient uptake by plants (Mengel and Kirkby, 1987), in addition to general weakness of plant conditions as a result of water stress that reflected on plant absorption and translocation (Abdel-Nasser and EL-Shazly, 2000).

\begin{tabular}{|c|c|c|c|}
\hline $\begin{array}{c}\text { Irrigation Treatment } \\
\left(\% \text { of } \mathrm{ET}_{0}\right)\end{array}$ & $\begin{array}{l}\text { Nitrogen } \\
(\%)\end{array}$ & $\begin{array}{c}\text { Phosphorus } \\
(\%)\end{array}$ & $\begin{array}{l}\text { Potassium } \\
(\%)\end{array}$ \\
\hline 20 & $1.23 \mathrm{~b}$ & $0.20 \mathrm{c}$ & $2.60 \mathrm{~b}$ \\
\hline 40 & $1.71 \mathrm{a}$ & $0.32 \mathrm{ab}$ & $3.02 \mathrm{ab}$ \\
\hline 60 & $1.74 \mathrm{a}$ & $0.29 b$ & $3.35 \mathrm{a}$ \\
\hline 80 & $1.47 \mathrm{ab}$ & $0.37 a b$ & $3.29 \mathrm{a}$ \\
\hline 100 & $1.34 \mathrm{~b}$ & $0.37 \mathrm{a}$ & $3.40 \mathrm{a}$ \\
\hline LSD (0.05) & $0.29^{*}$ & $0.05^{\star}$ & $0.60^{*}$ \\
\hline
\end{tabular}

*Means value followed by the same letter are not significant at 0.05 probability level

\section{Sunflower evapotranspiration and water requirements}

Sunflower seasonal evapotranspiration $\left(E T_{c}\right)$ was calculated according Penman-Monteith equation (Allen et al., 1998) and using the suitable crop coefficient by multiplying the reference evapotranspiration $\left(E T_{0}\right)$ by a crop coefficient $\left(\mathrm{K}_{\mathrm{c}}\right)$.

$$
\mathrm{ET}_{\mathrm{c}}=\mathrm{K}_{\mathrm{c}} \times \mathrm{ET}_{0}
$$

The seasonal $\mathrm{ET}_{\mathrm{c}}$ was illustrated in Table (9). It is account as 76.6, 153.2, 229.8, 306.4 and $383.0 \mathrm{~mm}$ for water regime of $20,40,60,80$ and $100 \%$ of reference evapotranspiration $\left(\mathrm{ET}_{0}\right)$, respectively. The irrigation water requirements $\left(\mathrm{m}^{3} \mathrm{ha}^{-1}\right)$ were calculated and illustrated in Table (9). The values of 
gross irrigation water requirement (GIWR) were 948.58, 1897.17, 2845.75, 3794.33 and $4742.92 \mathrm{~m}^{3} \mathrm{ha}^{-1}$, respectively.

\section{Water use efficiency (WUE) and Irrigation water use efficiency (IWUE)}

Water-use efficiency (WUE) is a common expression of plant productivity. It may represent the ratio of total above-ground dry biomass or dry seed weight to the seasonal evapotranspiration (ET). With this approach, different cultural practices can be assessed to determine optimum use of limited irrigation water.

Water use efficiency expressed as $\left(\mathrm{kg} \mathrm{m}^{-3}\right)$ of seeds as affected by the different water treatments is presented in Table (9). The highest value was attained at highest deficit $\left(20 \%\right.$ of $\left.\mathrm{ET}_{0}\right)$. Increasing water deficit increased the water use efficiency due to decreased applied water. Maximum value of water use efficiency was $6.14 \mathrm{~kg} \mathrm{~m}^{-3}$ for seed yield and $2.46 \mathrm{~kg} \mathrm{~m}^{-3}$ for oil yield at $20 \%$ of $\mathrm{ET}_{0}$. The lowest values of WUE were attained at full irrigation (100\% of $\left.\mathrm{ET}_{0}\right)$. Our results are in accordance with those of Nahla (2003), Kssab et al. (2012) and Abdel-Mawgoud et al. (2009) who reported that water use efficiency increased with the decrease of irrigation water. Also, IWUE of seed yield was increased with decreasing the water deficit. The highest value of IWUE for seed yield was attained at irrigation $20 \%$ of $\mathrm{ET}_{0}$ (while the lowest value was attained at irrigation with $100 \%$ of $\mathrm{ET}_{0}$ ). The same trend was noticed for IWUE of oil yield, but the values of WUE are more than the values of IWUE.

Table (9). Water use efficiency as affected by irrigation regimes

\begin{tabular}{|c|c|c|c|c|c|c|c|}
\hline $\begin{array}{l}\text { Irrigation } \\
\text { Treatment } \\
\left(\% \text { of } E_{0}\right)\end{array}$ & $\begin{array}{l}\mathrm{ET}_{0} \\
\mathrm{~mm}\end{array}$ & $\begin{array}{l}\mathrm{ET}_{\mathrm{c}} \\
\mathrm{mm}\end{array}$ & $\begin{array}{c}\text { GIWR } \\
\text { m }^{3} \mathbf{h a}^{-1}\end{array}$ & $\begin{array}{l}\text { WUE } \\
\text { of seed } \\
\mathrm{kg} \mathrm{m}^{-3}\end{array}$ & $\begin{array}{l}\text { WUE } \\
\text { of oil } \\
\mathrm{kg} \mathrm{m}_{3}^{-}\end{array}$ & $\begin{array}{c}\text { IWUE } \\
\text { of } \\
\text { seed } \\
\mathrm{kg} \mathrm{m}^{-3}\end{array}$ & $\begin{array}{l}\text { IWUE } \\
\text { of oil } \\
\mathrm{kg} \mathrm{m}^{-3}\end{array}$ \\
\hline 20 & 509.98 & 76.60 & 948.58 & 6.14 & 2.46 & 4.96 & 1.99 \\
\hline 40 & 509.98 & 153.20 & 1897.17 & 3.23 & 1.43 & 2.61 & 1.15 \\
\hline 60 & 509.98 & 229.79 & 2845.75 & 2.21 & 1.00 & 1.79 & 0.81 \\
\hline 80 & 509.98 & 306.39 & 3794.33 & 1.90 & 0.87 & 1.54 & 0.70 \\
\hline 100 & 509.98 & 382.99 & 4742.92 & 1.54 & 0.72 & 1.24 & 0.58 \\
\hline
\end{tabular}

The present results indicate that reducing plant water needs to be less than $100 \%$ of $\mathrm{ET}_{0}$ (deficit irrigation) significantly reduced grain yield which this response is indicative the effect of drought stress on grain yield. Reducing seed yield in condition of limited irrigation can be contributed to effect of water defect due to lack of water which is along with acceleration of aging and reduction of filling period of grain, the signals sent from roots to leaves and induced stomata and finally reduction of the proportion of net photosynthesis. It seems that a balanced intake of water during various developmental stages of flowering and grading improved grain yield of sunflower. Because during this stage the most important yield components (seed number in head and seed weight) is formed. Also enough watering during the vegetative stage causes leaf development and 
photosynthesis of plants. (Mazaheri laghab et al., 2001) stated that poor irrigation regime not only reduces leaf area and premature aging but also decrease of seed yield. In fact, the reason of seed yield loss due to drought stress a decrease in current photosynthesis and remobilization of during grain filling material can be attributed. The (Human et al., 1990) in their experiments under severe stress at flowering, pollination and seed formation known to cause yield reduction.

Decrease of oil percentage in control treatment is because increase of water consumption increases excessive vegetative growth and delayed maturation of immature seed in the time of harvest also reduction of the percentage of oil in the severe stress treatment is because of impaired grain filling, which increases the skin of sunflower seeds. Moisture stress actually reduces the number of seed in length of seed the amount of oil has distributed in smaller tank and the oil percentage has not been affected (Cox and Jolliff, 1986). Sunflower oil yield per unit area is because of grain yield per unit area and seed oil percentage.(Mozaffari et al.,1996) has quoted about the effect of drought stress on sunflower oil percentage that the oil percentage does not damage in drought stress because seed oil is quantity that controls by many genes.

In fact, the reduction of water consumption and drought stress depends on the stress intensity is decreased oil yield cultivars. The results showed decrease or not irrigation reduced the grain yield and also affected oil content and oil yield. Because Stress on reproductive processes such as flowering and Pollination causes highest grain yield, also reduced accordingly oil yield. In fact, enough watering, especially during the filling stage of sunflower seeds and can be useful and effective in increase of seed weight and save of enough oil. Adequate moisture can be effective in the thin shell and increase of percentage of seed kernel. Sunflower oil yield per unit area is obtained by grain yield per unit area and percentage of seed oil. (Andria et al.,1995) found a positive correlation between seed yield and oil yield, but they found no linear relationship between seed yield and oil percentage.

The benefits of deficit irrigation can be attributed to the following reasons:

- water loss through evaporation is reduced,

- the negative effect of drought stress during specific phenological stages on biomass partitioning between reproductive and vegetative biomass(harvest index) is reduced (Fereres and Soriano, 2007; Reynolds and Tuberosa, 2008) due to increases the reproductive organs (Karam et al., 2009),

- water production for the net assimilations of biomass is increased as drought stress is mitigated or crops become more hardened. This effect due to conservative behavior of biomass growth in response to transpiration (Steduto et al., 2007),

- water productivity for the net assimilations of biomass is increased due to the synergy between irrigation and fertilization (Steduto and Albrizio, 2005), and 
- negative agronomic conditions are avoided during crop growth, such as pests, diseases, anaeobic conditions in the root zone due to water logging (Pereira et al., 2002; Geerts et al., 2008).

\section{CONCLUSION}

Any restriction in the supply of irrigation water is likely to induce a decrease in crop yield. However, the impact of deficit irrigation on crop yield can be insignificant where the water stress is applied to the crop during specific growth stages that are less sensitive to moisture deficiency. Results from the present study indicated that sunflower growth, seed yield, yield components and oil content had been significantly affected by deficit irrigation. It seems that sowing sunflower with $80 \%$ of $\mathrm{ET}_{0}$ of deficit irrigation level, were the recommended treatments to raise sunflower seed and oil yields compared with the other deficit irrigation levels under the environmental conditions of this study. In case of deficit irrigation, reduced irrigation water during the flowering period should be avoided. But when seasonal irrigation water was limited, it seems that deficit irrigation ( $80 \%$ of $\mathrm{ET}_{0}$ ) should be applied for the irrigation efficiency.

\section{REFERENCES}

Abdel-Mawgoud, A. S. A., M. A. Gameh, S. H. Abd-Elaziz and M. M. El-Sayed (2009). Sunflowers water relations at various irrigation regimes with modern irrigation systems under climatic conditions of Assiut Governorate, upper Egypt. International Water Technology Conference, 13: 589-609.

Abdel-Nasser, G. (1991). Minimizing of water requirements in relation to plant growth and yield of tomatoes. Ph.D. Thesis, Faculty of Agriculture, Alexandria Univ.

Abdel-Nasser, G. and S. M. El-Shazly (2000). Irrigation management of Anna Apple Trees in relation to growth, yield, fruit quality, leaf constituents and plant water relations. Alex. J. Agric. Res., 45 (1): 225-247.

Abdel-Nasser, G. and A. H. A. Hussein (2001). Response of corn to Kfertilization under different soil moisture conditions. I. Growth, yield, leaf nutrients content and plant water relations. J. Adv. Agric. Res., 6 (1): $173-$ 194.

Ali, M. D. H., and L. T. Shui (2009). Potential evapotranspiration model for Muda Irrigation Project, Malaysia. Water Resour. Manage., 23: 57-69.

Allen, R. G., L. S. Pereira, D. Raes and M. Smith (1998). Crop evapotranspiration-Guidelines for computing crop water requirements-FAO Irrigation and drainage paper 56. FAO, Rome. Italy, 300: 6541.

Aminifar, J., G. H. Mohsenabadi, M. H. Biglouei and H. Samiezadeh (2012). Effect of deficit irrigation on yield, yield components and phenology of soybean cu Itivars in Rasht region. International Journal of AgriScience, 2(2): 185-191.

Andria, D. and F. Q. Chiaranda (1995). Yield and soil water uptake of sunflower sown in spring and summer. Agron J., 87:1122-1128.

AOAC (1995). Official Methods of Analysis 16th Ed, A.O.A.C Benjamin Franklin Station, Washington, D.C, U.S.A. pp $490-510$. 
Ashrafi, E., and K. Razmjoo (2009). Effect of Irrigation Regimes on Oil Content and Composition of Safflower (Carthamus tinctorius L.) Cultivars. J. Am. Oil Chem. Soc., $10: 1-8$.

Berglund, D. R. (2003). Irrigated sunflower. North Dakota State University Agriculture and University Extension. File No. FS0546. ISSN 0155 - 3054.

Beyazgul, M., Y. Kayam and F. Engelsman (2000). Estimation methods for crop water requirements in the Gediz Basin of western Turkey. Journal of Hydrology, 229: 19-26.

Carter, M. R. and E. G. Gregorich (2008). Soil sampling and methods of Analysis, Second Edition. Canadian Society of soil Science; Boca Raton, FL:CRC Press, 1264 pages.

Casadebaig, P., P. Debaeke and J. Lecoeur (2008). Thresholds for leaf expansion and transpiration response to soil water deficit in a range of sunflower genotypes. European Journal of Agronomy, 28: 646-654.

Cox, W. J. and G. D. Jolliff (1986). Growth and yield of sunflower and soybean under soil water deficits. Agron. J., 78: 226-230.

Doorenbos, J. and A. H Kassam (1979). Yield response to water. Irrigation and drainage paper 33. In: Landon, J.R. (Ed.). Booker tropical soil manual, Longman Inc., New York, U.S.A.

Fereres, E. and M. A. Soriano (2007). Deficit irrigation for reducing agricultural water use. Special issue on "Integrated approaches to sustain and improve plant production under drought stress". J. Exp. Bot., 58:147-159.

Fox, P. and J. Rockstrom (2000). Water harvesting for supplemental irrigation of cereal crops to overcome intra-seasonal dry-spells in the Sahel. Phys. Chem. Earth. Part B: Hydrol. Oceans Atmos., 25(3): 289-296.

Geerts, S., D. Raes, M. Garcia, J. Vacher, R. Mamani, J. Mendoza, R. Huanca, B. Morales, R. Miranda, J. Cusicanqui and C. Taboada (2008). Introducing deficit irrigation to stablize yields of quinoa (Chenopodium quinoa Willd.). Eur. J. Agron., 28: 427-436.

Hesse, P. R (1971). A Text Book of Soil Chemical Analysis. John Murray Williams Clowes and sons Ltd. London 324pp.

Human, J. J., D. Du Toit, H. D. Bezuidenhout and L. P. Bruin (1990). The influence of plant water stress on net photosynthesis and yield of sunflower. Crop Sci., 164: 231-241.

Jackson, M.L. (1973). Soil Chemical Analysis. Prentice-Hall, Inc. India.

Karam, F., R. Kabalan, J. Breidi, Y. Rouphael and T. Oweis (2009). Yield and water production functions of two durum wheat cultivars grown under different irrigation and nitrogen regimes. Agric. Water Manag., 96:603-615.

Karmeli, D. and J. Keller (1975). Trickle irrigation design. Rain-Bird Sprinkler Mfg. Co., Glendora, Calif. p.133.

Kassab, O. M., A. A. Ellil and M. A. El-Kheir (2012).Water Use Efficiency and Productivity of Two Sunflower cultivars as Influenced by three rates of drip Irrigation Water. Journal of Applied Sciences Research, 8(7): 3524-3529.

Klute, A. (1986). Water retention: laboratory methods. In: Methods of Soil Analysis, Part 1: Physical and Mineralogical Methods, 2nd edn. pp. 635662. American Society of Agronomy, Madison, Wisconsin, USA. 
Mazaheri laghab, H. F., H. N. Abyaneh and H. M. Vafaie (2001). Effects Supplemental irrigation on traits of three cultivars of sunflower in dry farming. J. of Agric. Res., 3(1): 44 -31.

Mengel, K. and E. A. Kirkby (1987). "Principles of Plant Nutrition". 4th Ed., International Potash Institute, Bern, Switzerland.

Mozaffari, K., A. Arshi and V. H. Zeinalikhnagah (1996). Effects of Drought on some traits of morphophysiology and yield components of sunflower seeds. Seed and Plant J., 12( 3): 24-30.

Nahla, A. H. (2003).Water regime of some crops grown under drip irrigation at El- Kharga Oasis.M.Sc.Thesis, Agric. Sci. Soils, Dept., Assiut Univ. Egypt.

Page, A. L., R. H. Miller and D. R. Jkeeney (1982). Methods of soil analysis part 2. Chemical and Microbiological properties, Second Edition Agronomy Monograph, No 9, Madison Wisconsin.

Pereira, L. S., T. Oweis and A. Zairi (2002). Irrigation management under water scarcity. Agric. Water Manag., 57: 175-206.

Reddy, A. R., K. V. Chaitanya and M. Vivekanandan (2004). Drought induced responses of photosynthesis and antioxidant metabolism in higher plants. J. Plant Physiol., 161: 1189-1202.

Reynolds, M. and R. Tuberosa (2008). Translational research impacting on crop productivity in drought-prone environments. Curr. Opin. Plant Biol., 11: $171-179$.

Richards, L.A. (ed.) (1972). Diagnosis and Improvement of Saline and Alkaline Soils. U.S. Dept. of Agric., Agric. Handbook No. 60.

Rowe, R. N. and D. V. Bearsell (1973). Water logging of fruit trees. Hort. Abstr., 43:533-548.

Sepaskhah, A. R. and M. H Khajehabdollahi (2005). Alternative furrow irrigation with different irrigation intervals for maize (Zea mays L.). Plant Prod. Sci.. 8: 592-600.

Shehata, M. M. and El-Khawas (2003). Effect of two Biofertilizer on growth parameters, yield characters, Nitrogenous Components, Nucleis Acids Content, Minerals, Oil Content, Protein Profiles and DNA Banding Pattern of Sunflower (Helianthus annus L. cv. Vedock) Yield. Pakistan J.Biological Sci., 6(14): 1257- 1268.

Smith, M., D. Kivumbi and L. K Heng (2002). Use of the FAO-CROPWAT model in deficit irrigation studies. Deficit irrigation practices, FAO Water Reports No. 22, Rome.

Snedecor, G. W. and W .G. Cochran (1991). Statistical Methods. Eight edition. lowa State Univ. Press, Ames. 503pp.

Statistix (2003). Statistix 8.2, Analytical Software for Window. Tallahassee, FL.

Steduto, P., T. C. Hsiao and E. Fereres (2007). On the conservative behavior of biomass water productivity. Irrig. Sci., 25: 189-207.

Steduto, P. and R. Albrizio (2005). Resource use-efficiency of field grown sunflower, sorghum, wheat and chickpea. II. Water use efficiency and comparison with radiation use efficiency. Agric. Forest Meteorol., 130: 269281.

Szilgyi, L. (2003). Influence of drought on seed yield components in common bean. Bulg. J. Plant Physiol. Special Issue, 320-330 
Williams, L. J. and H. Abdi (2010). Fisher's Least Significant Difference (LSD) Test. In Neil Salkind (Ed.), Encyclopedia of Research Design, Thousand Oaks, CA: Sage.

Xiao, G., Q. Zhang, Y. Xiong, M. Lin and J. Wang (2007). Integrating rainwater harvesting with supplemental irrigation into rain-fed spring wheat farming. Soil and Tillage Research, 93: 429-437.

$$
\text { الملخص العربي }
$$

النمو، الإنتاجية والإستهلاك المائي لمحصول زهرة الثمس تحت نظام الري بالتنقيط

$$
\begin{aligned}
& \text { عبد الله احمد قاسم'، جمال عبدالناصر خليل' ، محمود عبدالعزيز جمعة” } \\
& \text { وزارة الزراعة والري - الجمهورية اليمنية }
\end{aligned}
$$

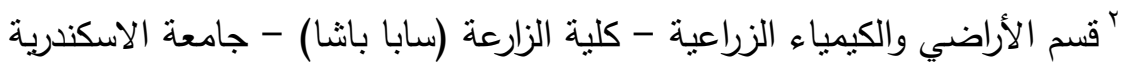

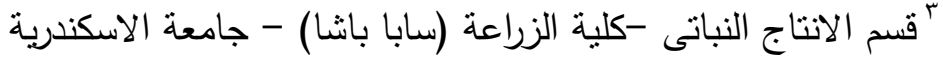

أجريت تجرية حقلية لمحصول زهرة الثمس مع انثاء نظام الري بالتقيط فى المزرعة البحثية لمحطة التجارب

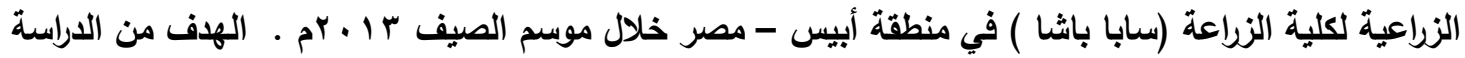

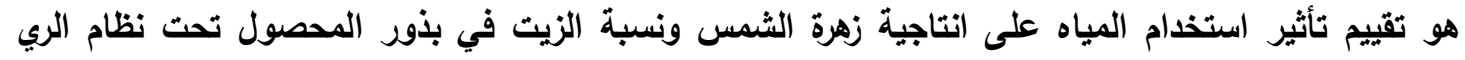

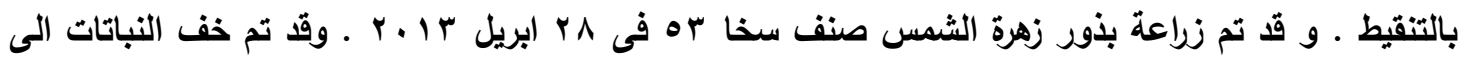

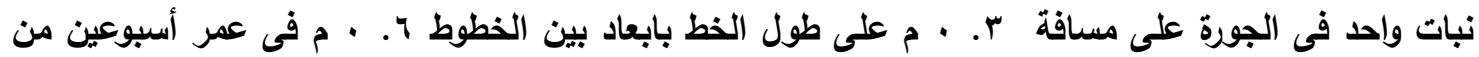

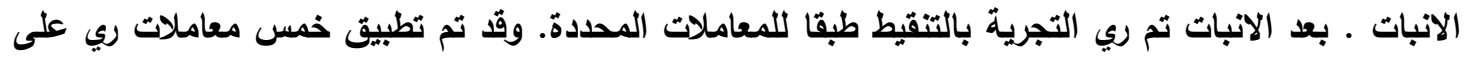
اساس معدل البخر-نتح المرجعي المقاس فى محطة الارصاد الجوية القريبة من موقع التجرية (مطار النزهة) .

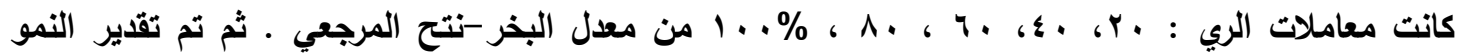
الخضري ، طول وعرض الجذور، والكلوروفيل ، والعناصر الغذائية الكبرى في اورلق النبات ، كمية الانتاج ونسبة

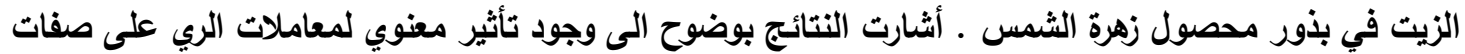

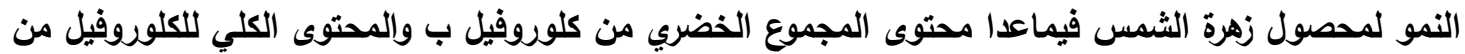

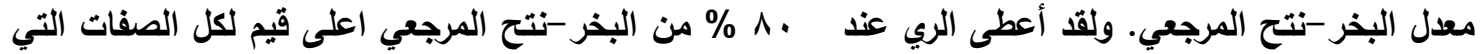

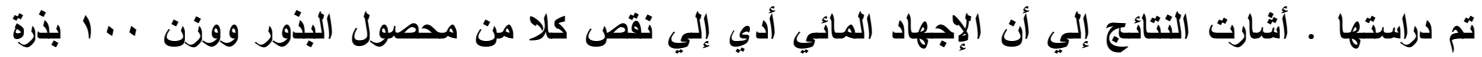

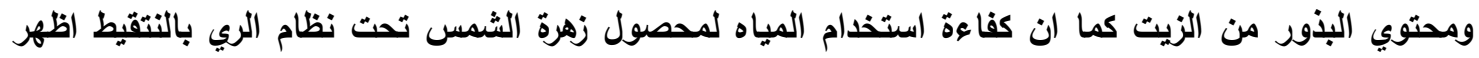

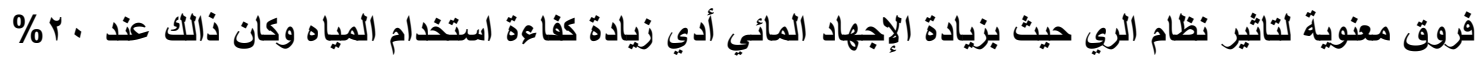

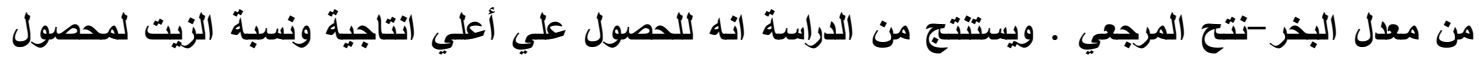

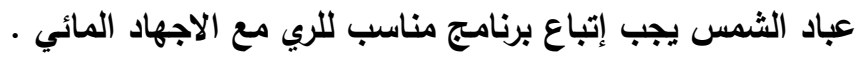

